\title{
Uptake of phytodetritus by benthic foraminifera under oxygen depletion at the Indian margin (Arabian Sea)
}

\author{
A. J. Enge ${ }^{1}$, U. Witte ${ }^{2}$, M. Kucera ${ }^{3}$, and P. Heinz ${ }^{1}$ \\ ${ }^{1}$ Department of Paleontology, University of Vienna, Geozentrum UZA 2, Althanstrasse 14, 1090 Vienna, Austria \\ ${ }^{2}$ Oceanlab, University of Aberdeen, Newburgh, Aberdeenshire AB41 6AA, UK \\ ${ }^{3}$ MARUM - Center for Marine Environmental Sciences, Leobener Strasse, 28359 Bremen, Germany
}

Correspondence to: A. J. Enge (annekatrin.enge@univie.ac.at)

Received: 3 May 2013 - Published in Biogeosciences Discuss.: 23 September 2013

Revised: 20 February 2014 - Accepted: 20 February 2014 - Published: 10 April 2014

\begin{abstract}
Benthic foraminifera in sediments on the Indian margin of the Arabian Sea, where the oxygen minimum zone (OMZ) impinges on the continental slope, are exposed to particularly severe levels of oxygen depletion. Food supply for the benthic community is high but delivered in distinct pulses during upwelling and water mixing events associated with summer and winter monsoon periods. In order to investigate the response by benthic foraminifera to such pulsed food delivery under oxygen concentrations of less than $0.1 \mathrm{~mL} \mathrm{~L}^{-1}$ $\left(4.5 \mu \mathrm{mol} \mathrm{L}{ }^{-1}\right)$, an in situ isotope labeling experiment $\left({ }^{13} \mathrm{C}\right.$, ${ }^{15} \mathrm{~N}$ ) was performed on the western continental slope of India at $540 \mathrm{~m}$ water depth (OMZ core region). The assemblage of living foraminifera $(>125 \mu \mathrm{m})$ in the uppermost centimeter at this depth is characterized by an unexpectedly high population density of 3982 individuals $10 \mathrm{~cm}^{-2}$ and a strong dominance by few calcareous species. For the experiment, we concentrated on the nine most abundant taxa, which constitute $93 \%$ of the entire foraminiferal population at $0-1 \mathrm{~cm}$ sediment depth. Increased concentrations of ${ }^{13} \mathrm{C}$ and ${ }^{15} \mathrm{~N}$ in the cytoplasm indicate that all investigated taxa took up labeled phytodetritus during the 4 day experimental phase. In total, these nine species had assimilated $113.8 \mathrm{mg} \mathrm{C} \mathrm{m}^{-2}$ (17.5\% of the total added carbon). Uptake of nitrogen by the three most abundant taxa (Bolivina aff. B. dilatata, Cassidulina sp., Bulimina gibba) was $2.7 \mathrm{mg} \mathrm{N} \mathrm{m}^{-2}$ ( $2 \%$ of the total added nitrogen). The response to the offered phytodetritus varied largely among foraminiferal species with Uvigerina schwageri being by far the most important species in short-term processing, whereas the most abundant taxa $\mathrm{Bo}$ livina aff. B. dilatata and Cassidulina sp. showed comparably low uptake of the offered food. We suggest the observed
\end{abstract}

species-specific differences are related to species biomass and specific feeding preferences. In summary, the experiment in the OMZ core region shows rapid processing of fresh phytodetritus by foraminifera under almost anoxic conditions. The uptake of large amounts of organic matter by few species within four days suggests that foraminifera may play an important role in short-term carbon cycling in the OMZ core region on the Indian margin.

\section{Introduction}

Most benthic deep-sea organisms feed on the organic matter that settles onto the sea floor and therefore depend on this material as their food source. Phytoplankton detritus (phytodetritus), which is a main food source for benthic foraminifera (Gooday and Hughes, 2002; Lambshead and Gooday, 1990), typically arrives at the sea floor in pulses delivered from seasonal surface production (Beaulieu and Smith, 1998; Gage and Tyler, 1991; Gooday, 2002; Gooday and Turley, 1990). Benthic foraminifera can respond very quickly to the pulses of phytodetritus to the sediment surface (Altenbach, 1992; Drazen et al., 1998; Enge et al., 2011; Gooday and Turley, 1990; Graf, 1989; Linke et al., 1995). Additionally, they are common inhabitants of marine sediments. Therefore, they play a quantitatively important role in short-term processing of phytodetritus on the floor of the world's oceans (Moodley et al., 2002).

Oxygen-depleted water masses (oxygen minimum zones, OMZs) develop in areas with high surface production and limited water replenishment (Kamykowski and Zentara, 
1990). These natural hydrographic features, characterized by dissolved oxygen concentrations $<0.5 \mathrm{~mL} \mathrm{~L}^{-1}$ $\left(22.3 \mu \mathrm{mol} \mathrm{L}{ }^{-1}\right)$, are especially well developed at intermediate water depths in the North Pacific, the Arabian Sea, and the Bay of Bengal (Helly and Levin, 2004; Wyrtki, 1971). Where they impinge on continental margins at shelf to upper bathyal depths, strong bottom-water oxygen gradients are developed. Sediments rich in organic matter are typically associated with OMZs. Benthic organisms found within these sediments can benefit from this enhanced food supply, but they must be able to tolerate the very low-oxygen concentrations that are permanently present in the core regions of OMZs.

An unusually high tolerance to hypoxia among eukaryotic benthos has been observed for benthic foraminifera in strongly oxygen-depleted areas such as the southern California borderland basins, Scandinavian fjords, and OMZ sediments (Bernhard and Sen Gupta, 1999). Being able to perform respiration by denitrification in the absence of oxygen was first observed for two benthic species by RisgaardPetersen et al. (2006). This surprising ability to accumulate nitrate and its respiration to dinitrogen gas was later confirmed in benthic foraminifera in OMZ sediments off the Chilean coast (Hogslund et al., 2008) and demonstrated in laboratory experiments (Pina-Ochoa et al., 2010). However, in at least one species, symbiotic bacteria appear to be responsible for respiring the nitrate, not the foraminifera (Bernhard et al., 2012). Since most other eukaryotic organisms, especially macrofauna, are not as tolerant to hypoxia as foraminifera (Josefson and Widbom, 1988), they often are absent from sediments in the core of the OMZ (Gooday et al., 2009). Due to their unique metabolism, combined with the absence of macrofaunal competition, foraminifera are thus able to proliferate under extreme low-oxygen conditions. In the OMZ sediments in the Arabian Sea, recent foraminifera are abundant components of the benthic community as observed in studies performed on the Pakistan margin (Gooday et al., 2009; Jannink et al., 1998; Maas, 2000; Schumacher et al., 2007) and Oman margin (Gooday et al., 2000; Hermelin and Shimmield, 1990). Their abundant occurrence in OMZ sediments, combined with the ability to utilize fresh labile organic matter and tolerate low-oxygen concentrations, suggest that benthic foraminifera might play an important role in carbon cycling in OMZ sediments in the Arabian Sea.

In situ feeding experiments using ${ }^{13} \mathrm{C}$-labeled food have been shown to be an effective approach to study the metabolic response of foraminifera to phytodetritus deposition under natural conditions (e.g., Witte et al., 2003; Nomaki et al., 2005; Enge et al., 2011). In OMZ sediments on the Pakistan margin, Woulds et al. (2007) and Andersson et al. (2008) performed a series of labeling experiments along a depth transect $(140-1850 \mathrm{~m})$ focusing on the role of the benthic fauna in sedimentary processes. Both studies demonstrated the influence of oxygen on the processing of organic matter by organisms and the importance of foraminifera to carbon cycling in oxygen-depleted environments. Though Woulds et al. (2007) and Andersson et al. (2008) included foraminifera in their studies, they did not discriminate between species but compared the foraminiferal response to the reaction of macrofauna, meiofauna and bacteria.

In our experiments, we were interested to study the response of individual species of foraminifera to a pulse of fresh phytodetritus under low-oxygen concentration. To ensure almost anoxic conditions, an in situ labeling experiment was carried out in the core region of the OMZ $\left(<0.1 \mathrm{~mL} \mathrm{O}_{2} \mathrm{~L}^{-1}\right)$ on the Indian margin. Recently, Jeffreys et al. (2013) performed a dual labeling experiments on macrofauna-sized foraminifera in the abyssal northeast Pacific, but did not discriminate between species. In the present study, the following hypotheses will be tested: (1) foraminifera from the $\mathrm{OMZ}$ core display a positive feeding response to phytodetritus within four days, (2) uptake rates will vary between species, and (3) relative uptake of carbon to nitrogen is species-specific.

\section{Material and methods}

\subsection{Study area}

The study was part of an international research project on benthic ecology, geochemistry and biogeochemical processes across the oxygen minimum zone on the Indian margin in the Arabian Sea. The collaborative research cruise "YK08-11" aboard the R/V Yokosuka of the Japan Agency for Marine-Earth Science and Technology (JAMSTEC) took place between September and November 2008. The area of interest was the sea floor of the Indian margin in the Arabian Sea, exposed to the OMZ water mass. Detailed sampling sites are shown in Hunter et al. (2012). OMZ influenced sediments of the Indian margin are found between 120-1100 m (Helly and Levin, 2004).

The feeding experiment was carried out from 9 to 13 October 2008 (post-monsoonal period) during the first leg of the cruise at $540 \mathrm{~m}$ water depth $\left(16^{\circ} 58^{\prime} \mathrm{N}\right.$ and $\left.71^{\circ} 55^{\prime} \mathrm{E}\right)$. This depth is located in the core region of the Indian margin OMZ and corresponds to station T1 540 in the study of Hunter et al. (2011).

The area of interest shows a moderate to high average yearly productivity of $>0.5-0.75 \mathrm{~g} \mathrm{C} \mathrm{m}^{-2} \mathrm{~d}^{-1}$ (Babu et al., 1999). The intense productivity in the Arabian Sea is driven by monsoon-induced upwelling in summer (SW monsoon) and deep mixing of water masses in winter (NE monsoon). This results in distinctly seasonal surface primary production and organic matter flux. In October 2008, the particulate organic carbon concentration was $100-200 \mathrm{mg} \mathrm{m}^{-3}$ (SeaWiFS, NASA OceanColor; monthly POC data). Environmental data were obtained during dives by the submersible Shinkai 6500 (JAMSTEC, 2007) and derive from CTD recordings and measurements with an optical oxygen sensor (Hunter 
et al., 2011). At the time of sampling, in situ oxygen concentrations ranged between $0.02 \mathrm{~mL} \mathrm{~L}^{-1}\left(0.9 \mu \mathrm{mol} \mathrm{L}^{-1}\right)$ and $0.05 \mathrm{~mL} \mathrm{~L}^{-1}\left(2.4 \mu \mathrm{mol} \mathrm{L}^{-1}\right)$ and temperature was $12{ }^{\circ} \mathrm{C}$ (Table 1). As recordings of environmental parameters were continuous, values given in Table 1 represent averages for $540 \mathrm{~m}$ depth. Surface sediment characteristics (\% total organic carbon (TOC), \% total nitrogen (TN), porosity) are given in Hunter et al. (2011).

\subsection{Preparation of ${ }^{13} \mathrm{C}$ - and ${ }^{15} \mathrm{~N}$-labeled algae}

Before the cruise, an axenic clone of the diatom Thalassiosira weissflogii (CCMP, Bigelow Laboratories for Ocean Science, USA) was cultured in artificial seawater and $L 1$ culture medium, enriched with $99 \%-{ }^{13} \mathrm{C}$-bicarbonate $\left(\mathrm{NaH}^{13} \mathrm{CO}_{3}\right.$, Cambridge Isotope Laboratories, Inc., USA) and $50 \%-{ }^{15} \mathrm{~N}$-sodium nitrate $\left(\mathrm{Na}^{15} \mathrm{NO}_{3}\right.$, Cambridge Isotope Laboratories, Inc., USA). Algae were cultured at $16^{\circ} \mathrm{C}$ for $28 \mathrm{~d}$ (light: dark $=16: 8 ; 35$ PSU), harvested by centrifugation $(500 \mathrm{G} ; 30 \mathrm{~min})$, sonicated $(2000 \mathrm{~Hz} ; 5 \mathrm{~min})$ and rinsed three times in ultrapure water to remove inorganic salts and dissolved organic carbon. Harvested algae were lyophilized $\left(-60{ }^{\circ} \mathrm{C} ;-0.0001 \mathrm{mbar} ; 24 \mathrm{~h}\right)$ to produce phytodetritus containing 27.75 atom $\%{ }^{13} \mathrm{C}$ and 33.70 atom $\%{ }^{15} \mathrm{~N}$ (Hunter et al., 2012).

\subsection{Experimental setup}

For the feeding experiment we used Oceanlab spreader systems. This in situ mesocosm consisted of a transparent polycarbonate tube $(25 \mathrm{~cm}$ inner diameter, $30 \mathrm{~cm}$ length) and a lid that contained the suspension of $T$. weissflogii (650 $\mathrm{mg} \mathrm{C} \mathrm{m}^{-2}, 160 \mathrm{mg} \mathrm{N} \mathrm{m}^{-2}$ ). More detailed information about the construction can be found in Hunter et al. (2012). On 9 October 2008, the manipulator arm of the manned submersible Shinkai 6500 pushed three spreaders straight into the undisturbed sea floor until they stood firmly upright. By pushing the plunger on the lid, the suspension of alga was released from the container and settled to the enclosed sediment surface. To ensure complete deposition of the algae mass onto the sediment surface, the spreader lid was removed several hours after the deployment of the spreader. Incubation of the enclosed sediment surface with the labeled diatoms lasted four days. The amount of food applied and the open system with continuous water exchange guaranteed optimal simulation of natural conditions.

After four days, one push core (plastic tube, $70 \mathrm{~mm}$ inner diameter) for foraminiferal analysis was recovered from inside each spreader by the submersible. The Oceanlab spreader system was removed afterwards. On board the research vessel, the push core was immediately sliced horizontally in $1 \mathrm{~cm}$ intervals down to $3 \mathrm{~cm}$ depth. Each slice was frozen at $-80^{\circ} \mathrm{C}$ and then stored at $-25^{\circ} \mathrm{C}$ until analyzed. For our study, we investigated the assemblage and the isotope composition of foraminifera from the $0-1 \mathrm{~cm}$ layer of one push core. We concentrated on the upper $1 \mathrm{~cm}$ because living foraminifera in OMZ sediments of the Arabian Sea are largely restricted to the upper sediment layer (e.g., Jannink et al., 1998; Larkin and Gooday, 2009; Maas, 2000; Schumacher et al., 2007). The need for between 200 and 1500 individuals for a single isotope measurement made replication difficult given the available time and manpower. However, we were able to analyze carbon in duplicate batches for four species (Table 2).

\subsection{Sample preparation}

In the laboratory, the $0-1 \mathrm{~cm}$ sediment sample was thawed and washed over a mesh $(125 \mu \mathrm{m})$ with artificial seawater (composition see Enge et al., 2011). After sieving, the residue was frozen at $-25^{\circ} \mathrm{C}$ until further processing. Separation of living and dead specimens was based on visual assessment of cytoplasm presence and the degree to which it filled the test (Moodley et al., 2002; Nomaki et al., 2005, 2006; Sweetman et al., 2009). Foraminifera were wet-picked from the residue in a petri dish, which was placed on a cooling plate for the entire duration of the picking process. The entire $0-1 \mathrm{~cm}$ sample was investigated for faunal composition of living foraminifera. We identified foraminifera by species level as far as possible. Counts showed that nine taxa were represented by sufficient specimens and biomass for stable isotopic analyses. To meet the minimum of biomass requirements for isotope analysis, individuals of one species were pooled. The required number of individuals varied among species according to size and biomass, the maximum number per analysis being 1500 individuals (Table 2).

Before processing, material for isotopic analysis, glassware and silver cups were combusted $\left(450{ }^{\circ} \mathrm{C}, 5 \mathrm{~h}\right)$ and picking tools were cleaned with a mixture of dichloromethane and methane $(1: 1, v: v)$ to be free of organic contaminants. All foraminifera were carefully brushed and washed twice in filtered artificial seawater to ensure they were free from organic matter adhering on the outside of the test. After filling silver cups with $10 \mu \mathrm{L}$ of filtered seawater, foraminifera were transferred into cups with a brush. Subsequently, we dried the filled cups at $50^{\circ} \mathrm{C}$ for several hours before adding hydrochloric acid (6.25\%) to ensure complete dissolution of carbonate.

We observed that the decalcification process involved production of carbon dioxide, which could cause overflow of organic matter out of the silver cup. Hence, the transfer of foraminifera into one cup had to be performed stepwise and not at once. The procedure of transferring specimens to silver cups, heating and adding hydrochloric acid was repeated until all calcareous parts of the foraminifera were dissolved. Finally, samples were kept at $50^{\circ} \mathrm{C}$ for three days to allow complete drying. 
Table 1. Environmental parameters at $540 \mathrm{~m}$ water depth during the time of the experiment. Data derive from CTD recordings and measurements by an optical oxygen sensor during deployment and recovery of spreaders/push cores.

\begin{tabular}{llllllll}
\hline Date & $\begin{array}{l}\text { Water depth } \\
(\mathrm{m})\end{array}$ & Longitude & Latitude & $\begin{array}{l}\mathrm{O}_{2} \\
\left(\mu \mathrm{molL} \mathrm{L}^{-1}\right)\end{array}$ & $\begin{array}{l}\mathrm{O}_{2} \\
\left(\mathrm{mLL}^{-1}\right)\end{array}$ & $\begin{array}{l}\text { Temperature } \\
\left({ }^{\circ} \mathrm{C}\right)\end{array}$ & $\begin{array}{l}\text { Salinity } \\
(\mathrm{PSU})\end{array}$ \\
\hline 9 Oct 2008 & 540 & $16^{\circ} 58.8^{\prime} \mathrm{N}$ & $71^{\circ} 55.3^{\prime} \mathrm{E}$ & 0.9 & 0.02 & 11.7 & 35.2 \\
13 Oct 2008 & 540 & $16^{\circ} 58.8^{\prime} \mathrm{N}$ & $71^{\circ} 55.3^{\prime} \mathrm{E}$ & 2.4 & 0.05 & 12.1 & 35.2 \\
\hline
\end{tabular}

Table 2. Number of specimens analyzed for ${ }^{13} \mathrm{C} /{ }^{12} \mathrm{C}$ (nine species) and ${ }^{15} \mathrm{~N} /{ }^{14} \mathrm{~N}$ (three species), the calculated content of $\mathrm{C}$ and $\mathrm{N}$ per individual (average) and the $\delta^{13} \mathrm{C}$ and $\delta^{15} \mathrm{~N}$ of foraminifera after exposure to labeled food.

\begin{tabular}{|c|c|c|c|c|c|}
\hline Species & $\begin{array}{l}\text { Measured } \\
\text { individuals }\end{array}$ & $\begin{array}{l}\text { C content } \\
\left(\mu \text { individual }^{-1}\right)\end{array}$ & $\begin{array}{l}\mathrm{N} \text { content } \\
\left(\mu \text { individual }^{-1}\right)\end{array}$ & $\begin{array}{l}\delta^{13} \mathrm{C} \\
(\% o)\end{array}$ & $\begin{array}{l}\delta^{15} \mathrm{~N} \\
(\% o)\end{array}$ \\
\hline \multirow[t]{3}{*}{ Bolivina aff. $B$. dilatata } & 400 & 0.124 & - & 700.4 & - \\
\hline & 400 & 0.128 & - & 723.4 & - \\
\hline & 1500 & - & 0.010 & - & 5258.3 \\
\hline \multirow[t]{2}{*}{ Bulimina gibba } & 250 & 0.312 & - & 2630.3 & - \\
\hline & 600 & - & 0.023 & - & 14924.7 \\
\hline \multirow[t]{3}{*}{ Cassidulina sp. } & 300 & 0.108 & - & 505.0 & - \\
\hline & 300 & 0.103 & - & 374.7 & - \\
\hline & 1500 & - & 0.010 & - & 7191.0 \\
\hline \multirow[t]{2}{*}{ Ehrenbergina pacifica } & 350 & 0.251 & - & 174.6 & - \\
\hline & 300 & 0.226 & - & 115.5 & - \\
\hline Epistominella rugosa & 400 & 0.140 & - & 674.6 & - \\
\hline Hoeglundina cf. elegans & 200 & 0.235 & - & 6182.6 & - \\
\hline Lenticulina spp. & 200 & 0.565 & - & 230.9 & - \\
\hline Uvigerina schwageri & 200 & 1.363 & - & 9516.3 & - \\
\hline \multirow[t]{2}{*}{ Uvigerina peregrina } & 350 & 0.265 & - & 4903.4 & - \\
\hline & 300 & 0.232 & - & 5000.7 & - \\
\hline
\end{tabular}

\subsection{Calculation of phytodetritus uptake}

Total $\mathrm{C}$ and $\mathrm{N}$ content of foraminiferal cytoplasm as well as ${ }^{13} \mathrm{C} /{ }^{12} \mathrm{C}$ and ${ }^{15} \mathrm{~N} /{ }^{14} \mathrm{~N}$ ratios were measured at SI Science Co., Ltd. (Japan) using an elemental analyzer/isotoperatio mass spectrometer (EA/IRMS). Hereafter, the ratios ${ }^{13} \mathrm{C} /{ }^{12} \mathrm{C}$ and ${ }^{15} \mathrm{~N} /{ }^{14} \mathrm{~N}$ will be expressed as atom $\%{ }^{13} \mathrm{C}$ and atom $\%{ }^{15} \mathrm{~N}$. Formulas given in this section apply to the calculation of carbon uptake. Uptake of nitrogen was calculated with the same formulas but with different standards and different natural background values.

Carbon isotope composition was measured against the international Vienna Pee Dee Belemnite standard (VPDB) and nitrogen isotope composition relative to atmospheric nitrogen. Differences between sample and standard are expressed in $\delta$-notation: $\delta^{13} \mathrm{C}$ $\left[\%\right.$ o $=\left(\left(\right.\right.$ atom $\left.\%{ }^{13} \mathrm{C}_{\text {sample }}\right) /\left(\right.$ atom $\left.\left.\%{ }^{13} \mathrm{C}_{\mathrm{VPDB}}\right)-1\right) \times 1000$. Incorporation of ${ }^{13} \mathrm{C}$ and ${ }^{15} \mathrm{~N}$ by foraminifera was defined as excess above background (bkgd):

excess $_{\text {foram }}=\left(\right.$ atom $\%{ }^{13} \mathrm{C}_{\text {sample }}-$ atom $\left.\%{ }^{13} \mathrm{C}_{\mathrm{bkgd} \text { foram }}\right) / 100$,

while

excess $_{\text {algae }}=\left(\right.$ atom $\%{ }^{13} \mathrm{C}_{\text {alga }}-$ atom $\left.\%{ }^{13} \mathrm{C}_{\text {bkgd alga }}\right) / 100$.
Natural isotope (background) signatures for benthic foraminiferal cytoplasm of $\delta^{13} \mathrm{C}=-20.3$ and $\delta^{15} \mathrm{~N}=8.0$ derived from Enge et al. (2011), Nomaki et al. (2005, 2006, 2008), and Sweetman et al. (2009). In literature, $\delta^{13} \mathrm{C}$ literature values were available for different sediment depths and foraminiferal species. For our calculation, we used only natural signatures from calcareous species in the $0-1 \mathrm{~cm}$ layer. The natural signatures of the diatom Thalassiosira weissflogii (and food source in our experiment) with $\delta^{13} \mathrm{C}$ $=-21.2$ and $\delta^{15} \mathrm{~N}=4.9$ were taken from Aberle and Malzahn (2007).

Uptake $(\mathrm{mg} \mathrm{C})$ was calculated as product of excess in the sample and total carbon/nitrogen content in the sample, divided by the excess of labeled algae. Species uptake per seafloor area $\left(\mathrm{mg} \mathrm{C} \mathrm{m}^{-2}\right)$ was obtained by dividing the uptake per sample (mg C) by the number of analyzed specimens (Table 2 ) and then multiplying the individual uptake ( $\mathrm{mg} \mathrm{C}$ individuals ${ }^{-1}$ ) by the abundance (individuals $\mathrm{m}^{-2}$ ) found in the uppermost centimeter. The fraction $(f)$ of carbon and nitrogen originating from added alga material in the TOC/TON (total organic nitrogen) of analyzed foraminifera, was calculated after Nomaki et al. (2006):

$f_{\mathrm{C}}=\left(\right.$ atom $\%{ }^{13} \mathrm{C}_{\text {sample }}-$ atom $\left.\%{ }^{13} \mathrm{C}_{\text {bkgd foram }}\right) /\left(\right.$ atom $\%{ }^{13} \mathrm{C}_{\text {alga }}-$ atom $\left.\%{ }^{13} \mathrm{C}_{\text {bkgd alga }}\right)$. 


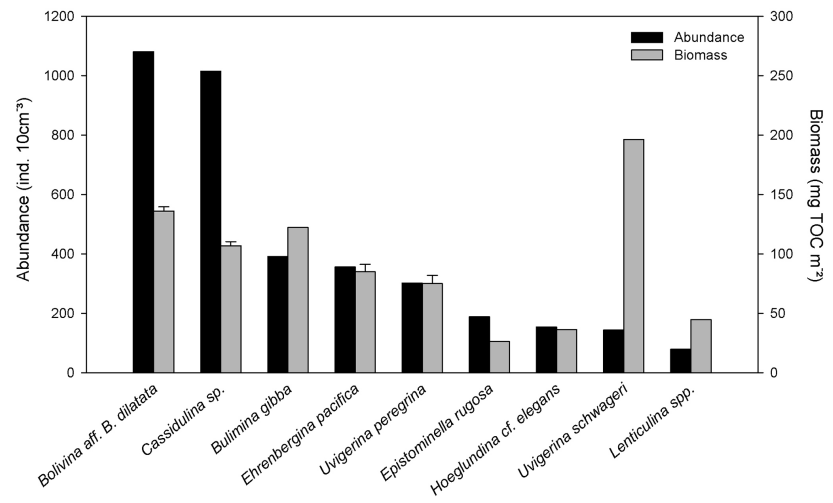

Fig. 1. Abundance (black bars) and biomass (grey bars, \pm SD) of the nine dominant species $(>125 \mu \mathrm{m})$ in the $0-1 \mathrm{~cm}$ sediment layer.

In addition, $f_{\mathrm{C}}$ also represents the biomass-normalized uptake of species, calculated as total $\mathrm{C}$ uptake per sample $(\mathrm{mgC})$ divided by the TOC content of the sample $(\mathrm{mgC})$. We also used the expression $f \times 100(\%)$ because calculated $f$ values were very small.

Species biomass for each species was estimated on the basis of mean individual TOC content and its abundance (in relation to sediment area).

\section{Results}

\subsection{Foraminiferal assemblage at $0-1 \mathrm{~cm}$}

The analyzed sediment (volume $38.5 \mathrm{~cm}^{3}$ ) yielded 15322 foraminifera assumed to have been living at the time of sampling. This amounts to a population density of 3982 individuals $10 \mathrm{~cm}^{-3}$ in the uppermost $\mathrm{cm}$ at $540 \mathrm{~m}$ water depth. Abundances of taxa ranged between 0.3 and 1081 individuals $10 \mathrm{~cm}^{-3}$. The assemblage consisted almost entirely of calcareous taxa $(99.5 \%)$. Agglutinated foraminifera represented the rest of the assemblage $(0.5 \%)$ while miliolids, allogromids, xenophyophores and soft-walled (agglutinated) foraminifera were absent in the $>125 \mu \mathrm{m}$ fraction. The community of living foraminifera in the analyzed size class was dominated by a low number of species. Bolivina aff. $B$. dilatata and Cassidulina sp. were the numerically most important taxa with densities of 1015 and 1081 individuals $10 \mathrm{~cm}^{-3}$ (Fig. 1), accounting for $27 \%$ and $25 \%$ of the entire foraminiferal abundance, respectively. The taxa Bulimina gibba (10\%), Ehrenbergina pacifica (9\%), Uvigerina peregrina $(8 \%)$, Epistominella rugosa (5\%), Hoeglundina cf. elegans (4\%), Uvigerina schwageri (4\%), and Lenticulina spp. $(2 \%)$ were also abundant. In total, these nine taxa accounted for $93.5 \%$ of the total population density.

The TOC content of species (calculated from the total TOC in the sample and the analyzed number of individuals), as well as species biomass, varied considerably among the nine most abundant species (Table 2, Fig. 1). Uvige-

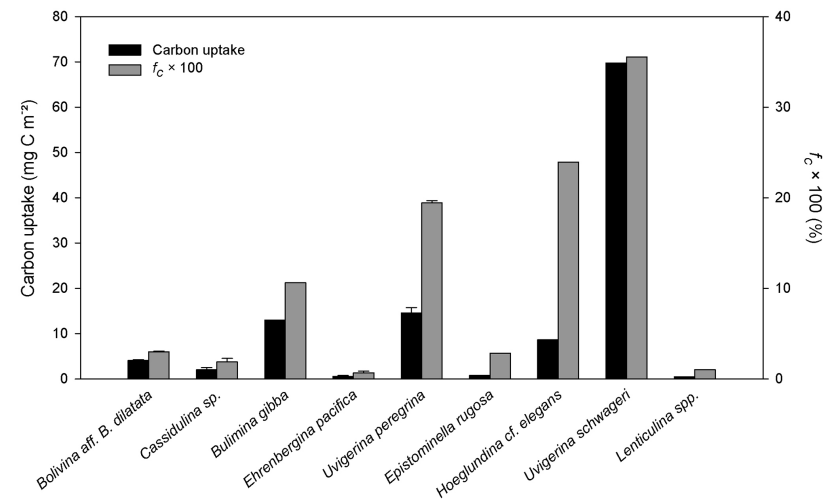

Fig. 2. Total carbon uptake of species and percentage of carbon originating from labeled algae in TOC of foraminiferal cytoplasm $\left(f_{\mathrm{C}} \times 100\right)$. Standard deviation is given for species with two replicate measurements.

rina schwageri yielded the highest TOC content and species biomass and was also largest in size. Based on the calculated individual TOC content and the total abundances of specimens in the uppermost $\mathrm{cm}$, we estimated the mean individual TOC content of each taxon in relation to the area of sediment (hereafter referred to as species biomass). Figure 1 shows the great variation of biomass between the nine foraminiferal taxa.

\subsection{Response to added carbon}

Uptake of phytodetritus was investigated for the nine most abundant species. They represented $93.5 \%$ of the total assemblage and were present in sufficient number for isotope analysis. In total, the cytoplasm of 7550 living individuals (Table 2) was analyzed for ${ }^{13} \mathrm{C} /{ }^{12} \mathrm{C}$ (nine taxa) and ${ }^{15} \mathrm{~N} /{ }^{14} \mathrm{~N}$ (three taxa). Measured $\delta^{13} \mathrm{C}$ values of $115.5-9516.3 \%$ exceeded natural isotopic values $(-20.3 \%$ ) substantially for all nine investigated species (Table 2). After four days, the nine taxa had taken up $113.8 \mathrm{mg} \mathrm{C} \mathrm{m}^{-2}$, which accounts for $17.5 \%$ of the added (labeled) carbon at the beginning of the experiment. The total uptake of carbon (as product of individual uptake and abundance) varied considerably among species (Fig. 2). Total carbon uptake was highest for $U$. schwageri with $69.8 \mathrm{mg} \mathrm{C} \mathrm{m}^{-2}$ (Table 3). Bulimina gibba, Hoeglundina cf. elegans and U. peregrina exhibited similar carbon uptake, ranging between 8.7 and $14.6 \mathrm{mg} \mathrm{C} \mathrm{m}^{-2}$. Lowest uptake $\left(<1 \mathrm{mg} \mathrm{C} \mathrm{m}^{-2}\right)$ was observed for E. pacifica and E. rugosa.

The uptake of labeled carbon per individual (representing an average value for all individuals of the species) also varied considerably between taxa. Lowest individual uptake was exhibited by E. pacifica with $1.6 \mathrm{ng} \mathrm{C}$, while the $\mathrm{C}$ uptake by $U$. schwageri yielded $484 \mathrm{ngC}$ per individual (Table 3). In order to test whether food uptake was a function of foraminiferal biomass, we calculated the biomass-normalized uptake or the fraction of algal carbon 
Table 3. (Mean) Carbon and nitrogen uptake $\left( \pm\right.$ SD) during 4 day experiment and the fractions of carbon $\left(f_{\mathrm{C}}\right)$ and nitrogen $\left(f_{\mathrm{N}}\right)$ originating from added algal material in foraminiferal cytoplasm.

\begin{tabular}{|c|c|c|c|c|c|c|}
\hline Species & $\begin{array}{l}\text { C uptake } \\
\left.\text { (ng Cindividual }^{-1}\right)\end{array}$ & $\begin{array}{l}\text { Total } \mathrm{C} \text { uptake } \\
\left(\mathrm{mgCm}^{-2}\right)\end{array}$ & $\begin{array}{l}f_{\mathbf{C}} \times 100 \\
(\%)\end{array}$ & $\begin{array}{l}\text { N uptake } \\
\left.\text { (ng Nindividual }^{-1}\right)\end{array}$ & $\begin{array}{l}\text { Total } \mathrm{N} \text { uptake } \\
\left(\mathrm{mgNm}^{-2}\right)\end{array}$ & $\begin{array}{l}f_{\mathbf{N}} \times 100 \\
(\%)\end{array}$ \\
\hline Bolivina aff. $B$. dilatata & $3.8 \pm 0.2$ & $4.1 \pm 0.2$ & 3.0 & 0.6 & 0.6 & 5.6 \\
\hline Bulimina gibba & 33.2 & 13.0 & 10.6 & 3.6 & 1.4 & 15.5 \\
\hline Cassidulina sp. & $2.0 \pm 0.5$ & $2.0 \pm 0.5$ & 1.9 & 0.7 & 0.7 & 7.7 \\
\hline Ehrenbergina pacifica & $1.6 \pm 0.5$ & $0.6 \pm 0.2$ & 0.7 & - & - & - \\
\hline Epistominella rugosa & 4.0 & 0.7 & 2.8 & - & - & - \\
\hline Hoeglundina $\mathrm{cf}$. elegans & 56.2 & 8.7 & 23.9 & - & - & - \\
\hline Lenticulina spp. & 5.8 & 0.5 & 1.0 & - & - & - \\
\hline Uvigerina schwageri & 484.4 & 69.8 & 35.6 & - & - & - \\
\hline Uvigerina peregrina & $48.2 \pm 3.9$ & $14.6 \pm 1.2$ & 19.4 & - & - & - \\
\hline
\end{tabular}

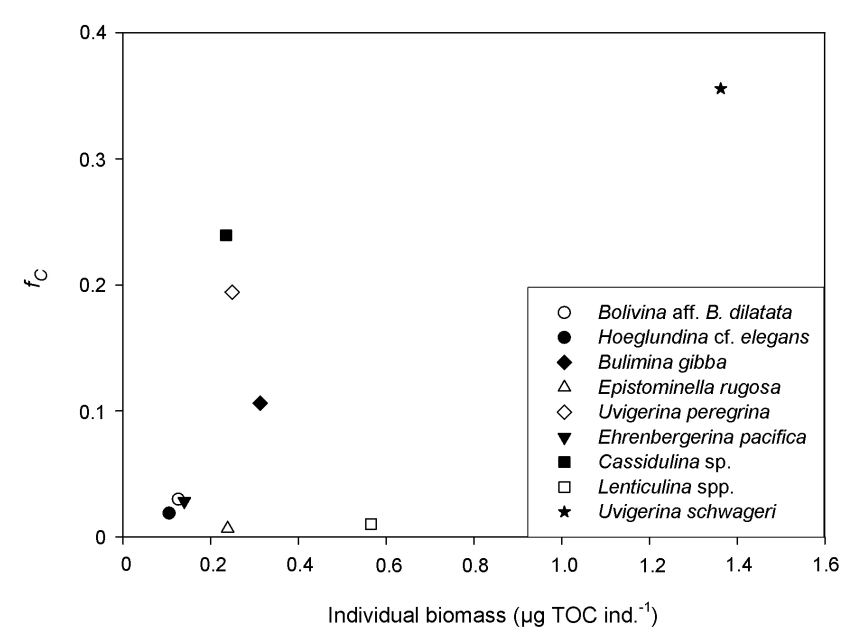

Fig. 3. Estimated individual TOC content of dominant species in relation to their biomass-normalized carbon uptake $\left(f_{\mathrm{C}}\right)$.

in foraminiferal cytoplasm $\left(f_{\mathrm{C}}\right)$. As illustrated in Fig. 3, $U$. schwageri displayed the highest biomass-normalized carbon content (0.36), followed by Hoeglundina cf. elegans (0.24), and U. peregrina (0.19). Lowest biomass-normalized uptake was calculated for E. pacifica.

\subsection{Response to added nitrogen}

Nitrogen isotope measurements were obtained for the three most abundant taxa ( $B$. aff. $B$. dilatata, Cassidulina sp., and $B$. gibba). Uptake of labeled nitrogen by $B$. gibba $\left(1.4 \mathrm{mg} \mathrm{N} \mathrm{m}^{-2}\right.$ ) was twice as high as by $B$. aff. $B$. dilatata and Cassidulina sp. (Table 3). The uptake of nitrogen for all three taxa was $2.7 \mathrm{mg} \mathrm{N} \mathrm{m}^{-2}$, which represents $1.7 \%$ of the added nitrogen at the start of the experiment. The same three taxa took up $19.1 \mathrm{mg} \mathrm{C} \mathrm{m}^{-2}$, which accounts for $2.9 \%$ of the $650 \mathrm{mg} \mathrm{C} \mathrm{m}^{-2}$.

The somatic $\mathrm{C}: \mathrm{N}$ ratio after the experimental phase ranged between 11 and 13.5 for the investigated taxa. Total uptake of carbon was higher than nitrogen for all species (Fig. 4) yet considerable differences occurred between species $(\mathrm{C}: \mathrm{N}$ of 6.6 for $B$. aff. B. dilatata, 2.7 for Cassidulina sp., and 9.6 for Bulimina aculeata).

\section{Discussion}

\subsection{Limitations of the study}

The vertical distribution of benthic foraminifera within the sediment is greatly influenced by the availability of food and the oxygen concentration with the pore water (Corliss and Emerson, 1990). In our analysis we concentrated on the response of foraminifera to food in the uppermost centimeter of the sediment $(0-1 \mathrm{~cm})$ because living foraminifera in the core region of OMZ sediments are mainly restricted to the upper sediment layer (e.g., Jannink et al., 1998, Schumacher et al., 2007) due to the extremely low-oxygen concentrations in these environments (see Table 1). Living foraminifera may be found in deeper sediment layers but with abundances negligible compared to the high numbers found in the $0-1 \mathrm{~cm}$ layer. Hence the results should represent an adequate picture of the foraminiferal community response in the size-fraction studied $(>125 \mu \mathrm{m})$. The results reported here derive from the extensive and time-consuming processing of sediment from one push core $(0-1 \mathrm{~cm})$, containing about 15300 counted specimens, of which 7550 were prepared and analyzed for stable isotope measurement. Due to limited manpower, the 63$125 \mu \mathrm{m}$ size fraction was not included in this study, which excludes a high number of smaller foraminifera and therefore underestimates the impact of the entire foraminiferal community on the phytodetritus processing. Despite these shortcomings, our data provide important information that is comparable to other studies. Carrying out experiments in the deep sea is not only limited by time and sampling equipment, but also by technical problems or bad weather. After the 4 day feeding experiment performed on the Indian margin at $540 \mathrm{~m}$ depth, only one push core from one spreader was available for foraminiferal analysis; the other push cores were used for other taxa. 


\subsection{Species-specific response to phytodetritus}

Individual responses to the added phytodetritus varied considerably among the nine taxa investigated with species uptake ranging from $0.5 \mathrm{mg} \mathrm{C} \mathrm{m}^{-2}$ for Lenticulina spp. to $69.8 \mathrm{mg} \mathrm{C} \mathrm{m}^{-2}$ for $U$. schwageri. Similar pronounced differences in short-term processing of phytodetritus between foraminiferal species under in situ experimental conditions have been observed in the bathyal Sagami Bay (Kitazato et al., 2003; Nomaki et al., 2005), the abyssal North Pacific (Enge et al., 2011) as well as on the Carolina margin (Levin et al., 1999). We suspect that several factors contribute to the occurrence of species-specific uptake of fresh phytodetritus in an environment of sufficient food supply but hostile environmental conditions.

As the calculation of total per-species uptake (per area) in our study is based on individual abundances, we expected the numerically dominating taxa $B$. aff. $B$. dilatata and Cassidulina sp. to show the highest uptake. However, uptake was lower than average for both taxa, contributing less to shortterm carbon cycling than species that were far less common at this site. This observation shows that the abundance is not the only control on species-level uptake of phytodetritus. Unfortunately, a correlation of species biomass and uptake was not observed for all species (e.g., B. gibba, U. peregrina, and Hoeglundina cf. elegans), although largest individual and species biomass was exhibited by $U$. schwageri, which also demonstrated the highest uptake of all species (Fig. 2) and highest content of labeled food after the experiment (Fig. 3).

As suggested by Nomaki et al. (2005) for foraminiferal populations from Sagami Bay, feeding preferences might play a very important role in the rate of uptake. In the eastern Arabian Sea diatoms are the dominating element of the phytoplankton community throughout the year (Sawant and Madhupratap, 1996). In our experiment the cosmopolitan diatom species Thalassiosira weissflogii was selected as a food source. The very high uptake by $U$. schwageri could suggest a preference for these diatoms, whereas $T$. weissflogii might be less acceptable to E. pacifica or Lenticulina spp., which exhibit lower levels of uptake. A preference of diatoms over coccolithophores was discovered for foraminifera in the abyssal Pacific by Jeffreys et al. (2013). In another in situ experiment, Nomaki et al. (2006) were able to identify selective feeders and random feeders on phytodetritus and sedimentary organic matter. Uvigerina akitaensis was one of the phytophageous species that ingested phytodetritus selectively. Different feeding preferences among species could be of advantage in an environment where competition for space and food must be very high among foraminiferal individuals, considering the standing stock of about 4000 individuals $10 \mathrm{~cm}^{-3}$.

In our study, $U$. schwageri showed highest uptake of all species by far; a third of this species' carbon content originated from labeled food. The association of the genera Uvigerina and Bulimina with areas of high productivity was

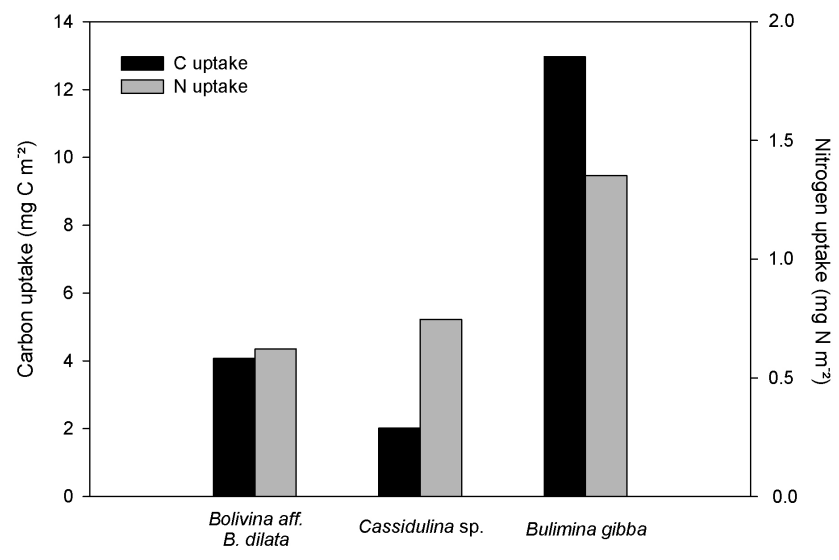

Fig. 4. Uptake of carbon (black) and nitrogen (grey) by the three most abundant species.

suggested by Loubere and Fariduddin (1999). In the eutrophic Sagami Bay, Uvigerina akitaensis and Bulimina aculeata dominated the foraminiferal response to phytodetritus during an in situ feeding experiment (Nomaki et al., 2005). Hence our observation of highest uptake by $U$. schwageri, $U$. peregrina, and $B$. gibba is consistent with these earlier observations and with the results of Woulds et al. (2007) where Uvigerina dominated short-term phytodetritus processing in the OMZ core on the Pakistan margin.

\subsection{Impact of foraminifera on carbon cycling in $\mathrm{OMZ}$ sediments}

Despite high interspecific differences in the uptake of food, all the investigated species demonstrated a positive reaction towards the presence of fresh phytodetritus within a very short amount of time. Within four days, foraminifera had taken up $114 \mathrm{mg} \mathrm{C} \mathrm{m}^{-2}$ with $U$. schwageri as the most important contributor. Our results reflect the uptake of food by the nine most abundant species in the size fraction $>125 \mu \mathrm{m}$. As we have no carbon uptake data for the remaining species at this sediment depth and excluded the size fraction < $125 \mu \mathrm{m}$, our results represent the minimum response of the entire assemblage. Therefore, carbon uptake by the entire foraminiferal community is expected to be higher and the impact on the benthic community utilization of fresh organic matter even greater.

The only comparable experimental studies to investigate the response of foraminifera to phytodetritus deposition in an OMZ setting were undertaken on the Pakistan margin by Woulds et al. (2007) and Andersson et al. (2008). The foraminiferal uptake in the OMZ core region ( $300 \mathrm{~m}$ depth) of the Pakistan margin ranged between 6 and $20 \mathrm{mg} \mathrm{C} \mathrm{m}^{-2}$ after 5 days of in situ incubation. The lower uptake compared to our experiment at the Indian margin $\left(114 \mathrm{mg} \mathrm{C} \mathrm{m}^{-2}\right)$ is very likely caused by the use of different mesh sizes. In our experiment, we used a $125 \mu \mathrm{m}$ mesh and found abundances 
of almost 4000 individuals $10 \mathrm{~cm}^{-3}$, whereas the study at the Pakistan margin yielded 200-336 individuals $10 \mathrm{~cm}^{-3}$ using a $300 \mu \mathrm{m}$ mesh (Woulds et al., 2007). As the calculation of carbon uptake per area is based on the estimated abundance of foraminifera, we assume that the exclusion of the 125-300 $\mu \mathrm{m}$ size fraction at the Pakistan study led to a lower abundance and hence to lower uptake. Foraminiferal uptake is thus comparable between the two OMZ core sites in the Arabian Sea.

Our results indicate that benthic foraminifera are able to utilize organic matter at oxygen concentrations of $<$ $0.1 \mathrm{~L} \mathrm{~mL}^{-1}$ as fast as in non-oxygen-depleted deep-sea environments (Kitazato et al., 2003; Nomaki et al., 2005; Enge et al., 2011; Nomaki et al., 2011). This suggests that foraminifera in the OMZ core on the Indian margin represent species highly adapted to low oxygen in order to be able to ingest large amounts of food. The absence of macrofauna at the investigation site (Hunter et al., 2012) might have also contributed to the observed uptake of phytodetritus by the foraminifera due to reduced competition for food. Where present on continental margins, metazoan organisms (polychaetes, nematodes) are important consumers of phytodetritus, reacting very quickly to its deposition (Andersson et al., 2008; Blair et al., 1996; Hunter et al., 2012; Levin et al., 1999; Woulds et al., 2007). Comparison of uptake to other potential consumers of phytodetritus like meiofauna or bacteria is hampered as relevant data are not available so far.

In situ experiments in the core region of the Pakistan margin OMZ (300 m) showed greater uptake of phytodetritus by bacteria than by foraminifera (Andersson et al., 2008). Similar environmental conditions between the two sites leads to the assumption that foraminifera on the Indian margin could also be important in short-term phytodetritus processing, as they are on the Pakistan margin.

\subsection{Uptake of nitrogen by foraminifera}

The three foraminiferal taxa that were analyzed for stable $\mathrm{N}$ isotopes all displayed high ${ }^{15} \mathrm{~N}$ values after the experiment, indicating that they had ingested nitrogen and that ${ }^{15} \mathrm{~N}$ can be used as a marker for food consumption on species level. More foraminiferal biomass and hence a greater number of specimens is required for the analysis of the nitrogen isotopic composition (Table 2) in comparison to carbon. Therefore, ${ }^{15} \mathrm{~N}$ is highly suitable as a marker for species with high population densities, whereas at abyssal or hadal depths its application could be hampered by the generally lower number of living foraminifera (e.g., Gooday, 1996; Ohkushi and Natori, 2001) compared to assemblages on continental margins.

The nitrogen uptake was lower in comparison to the uptake of carbon for all three species. The higher absolute uptake of labeled carbon by foraminifera, which has been also observed by Jeffreys et al. (2013), follows the natural higher demand for carbon over nitrogen to meet energetic requirements (Redfield ratio of 106:16). Though the absolute uptake of carbon was higher than for nitrogen in all three species, great differences were found in the species-specific uptake of $\mathrm{C}$ and $\mathrm{N}$ (see Sect. 3.3), suggesting that species have different metabolic demands in order to achieve homeostasis (Raubenheimer and Simpson, 2004).

\section{Conclusions}

The observed rapid response of foraminifera to fresh food input within 4 days is similar to that observed in other deepsea environments and is advantageous at times of enhanced food flux to the sea floor. The distinct variation in response to the presence of food stresses the importance of working at the species level in order to identify key species such as Uvigerina schwageri. The focus on individual species and their responses to food inputs can thus be very helpful for identifying key species for specific habitats and their use, for example, for paleo-reconstruction. The importance of a particular species in the processing of phytodetritus does not solely rely on its abundance but also on its size (biomass) and feeding preferences. Hence other key players might be found among the less abundant or smaller species. The high total uptake by these few species shows that foraminifera are well adapted to extremely low-oxygen concentrations and contribute to the carbon cycling in OMZ sediments. The ratio of $\mathrm{C}: \mathrm{N}$ uptake is different between species, which suggest that they may have different metabolic energy demands and possibly, therefore, different nutrition preferences.

Acknowledgements. We are grateful to Hiroshi Kitazato for the possibility to participate in the research cruise "YK08-11". Many thanks go to the captain and crew of the R/V Yokohama as well as to the pilots of the submersible Shinkai 6500 for the skillful operations. We also highly appreciate the help of Hidetaka Nomaki in organizing and helping in the isotopic measurements. We thank Andy Gooday and Claire Woulds for reviewing the manuscript and their help to improve the manuscript. This research was supported by the Deutsche Forschungsgemeinschaft (grant HE-2460/5-1 for A. Enge) and the Carnegie Trust (grant no. 008427 to U. Witte).

Edited by: A. Gooday

\section{References}

Aberle, N. and Malzahn, A. M.: Interspecific and nutrientdependent variations in stable isotope fractionation: experimental studies simulating pelagic multitrophic systems, Oecologia, 154, 291-303, 2007.

Altenbach, A. V.: Short-term processes and patterns in the foraminiferal response to organic flux rates, Mar. Micropaleontol., 19, 119-129, 1992.

Andersson, J. H., Woulds, C., Schwartz, M., Cowie, G. L., Levin, L. A., Soetaert, K., and Middelburg, J. J.: Short-term fate of phytodetritus in sediments across the Arabian Sea Oxygen Minimum 
Zone, Biogeosciences, 5, 43-53, 2008,

http://www.biogeosciences.net/5/43/2008/.

Babu, C. P., Burmsack, H.-J., and Schnetger, B.: Distribution of organic carbon in surface sediments along the eastern Arabian Sea: a revisit, Mar. Geol., 162, 91-103, 1999.

Beaulieu, S. E. and Smith, K. L. J.: Phytodetritus entering the benthic boundary layer and aggregated on the sea floor in the abyssal NE Pacific: macro- and microscopic composition, Deep-Sea Res. Pt. II., 45, 781-815, 1998.

Bernhard, J. M. and Sen Gupta, B. K.: Foraminifera of oxygendepleted environments, in: Modern Foraminifera, edited by: Sen Gupta, B. K., Kluwer Academic Publishers, Dordrecht, 201-216, 1999.

Bernhard, J. M., Edgcomb, V. P., Casciotti, K. L., McIlvin, M. R., and Beaudoin, D. J.: Denitrification likely catalyzed by endobionts in an allogromiid foraminifer, ISME J., 6, 951-960,2012.

Blair, N. E., Levin, L. A., DeMaster, D. J., and Plaia, G.: The shortterm fate of fresh algal carbon in continental slope sediments, Limnol. Oceanogr., 41, 1208-1219, 1996.

Corliss, B. H. and Emerson, S.: Distribution of Rose Bengal stained deep-sea benthic foraminifera from the Nova Scotian continental margin and Gulf of Maine, Deep-Sea Res., 37, 381-400, 1990.

Drazen, J. C., Baldwin, R. J., and Smith, K. L. J.: Sediment community response to a temporally varying food supply at an abyssal station in the NE Pacific. Deep-Sea Res. Pt. II, 45, 893-913, 1998.

Enge, A. J., Nomaki, H., Ogawa, N. O., Witte, U., Moeseneder, M. M., Lavik, G., Ohkouchi, N., Kitazato, H., Kucera, M., and Heinz, P.: Response of the benthic foraminiferal community to a simulated short-term phytodetritus pulse in the abyssal North Pacific, Mar. Ecol.-Prog. Ser., 438, 129-142, 2011.

Gage, J. D. and Tyler, P. A.: Deep-sea biology: a natural history of organisms at the deep-sea floor, Cambridge University Press, Cambridge, 504 pp., 1991.

Gooday, A. J.: Epifaunal and shallow infaunal foraminiferal communities at three abyssal NE Atlantic sites subject to differing phytodetritus input regimes, Deep-Sea Res. Pt. I, 43, 1395-1421, 1996.

Gooday, A. J.: Biological responses to seasonally varying fluxes of organic matter to the ocean floor: a review, J. Oceanogr., 58, 305$332,2002$.

Gooday, A. J. and Hughes, J. A.: Foraminifera associated with phytodetritus deposits at a bathyal site in the northern Rockall Trough (NE Atlantic): seasonal contrasts and a comparison of stained and dead assemblages, Mar. Micropaleontol., 46, 83110,2002

Gooday, A. J. and Turley, C. M.: Response by benthic organisms to inputs of organic material to the ocean floor - a review, Philos. Tr. R. Soc. Lond., 331, 119-138, 1990.

Gooday, A. J., Bernhard, J. M., Levin, L. A., and Suhr, S. B.: Foraminifera in the Arabian Sea oxygen minimum zone and other oxygen-deficient settings: taxonomic composition, diversity, and relation to metazoan faunas, Deep-Sea Res. Pt. II, 47, 25-54, 2000.

Gooday, A. J., Levin, L. A., da Silva, A. A., Bett, B. J., Cowie, G. L., Dissard, D., Gage, J. D., Hughes, D. J., Jeffreys, R., Lamont, P. A., Larkin, K. E., Murty, S. J., Schumacher, S., Whitcraft, C., and Woulds, C.: Faunal responses to oxygen gradients on the Pak- istan margin: a comparison of foraminiferans, macrofauna and megafauna, Deep-Sea Res. Pt. II, 56, 488-502, 2009.

Graf, G.: Benthic pelagic coupling in a deep-sea community, Nature, 341, 437-439, 1989.

Helly, J. J. and Levin, L. A.: Global distribution of naturally occurring marine hypoxia on continental margins, Deep-Sea Res. Pt. I, 51, 1159-1168, 2004.

Hermelin, J. O. R. and Shimmield, G. B.: The importance of the oxygen minimum zone and sediment geochemistry in the distribution of recent benthic foraminifera in the northwest Indian Ocean, Mar. Geol., 91, 1-29, 1990.

Hogslund, S., Revsbech, N. P., Cedhagen, T., Nielsen, L. P., and Gallardo, V. A.: Denitrification, nitrate turnover, and aerobic respiration by benthic foraminiferans in the oxygen minimum zone off Chile, J. Exp. Mar. Biol. Ecol., 359, 85-91, 2008.

Hunter, W. R., Oguri, K., Kitazato, H., Ansari, Z. A., and Witte, U.: Epi-benthic megafaunal zonation across an oxygen minimum zone at the Indian continental margin, Deep-Sea Res. Pt. I, 58, 699-710, 2011.

Hunter, W. R., Levin, L. A., Kitazato, H., and Witte, U.: Macrobenthic assemblage structure and organismal stoichiometry control faunal processing of particulate organic carbon and nitrogen in oxygen minimum zone sediments, Biogeosciences, 9, 993-1006, 2012 ,

http://www.biogeosciences.net/9/993/2012/.

Jannink, N. T., Zachariasse, W. J., and Van der Zwaan, G. J.: Living (Rose Bengal stained) benthic foraminifera from the Pakistan continental margin (northern Arabian Sea), Deep-Sea Res. Pt. I, 45, 1483-1513, 1998.

Jeffreys, R.M., Burke, C., Jamieson, A.J., Narayanaswamy, B.E., Ruhl, H.A., Smith, Jr., K.L., Witte, U.: Feeding preferences of abyssal macrofauna inferred from in situ pulse chase experiments. PloS ONE, 8, 11, e80510, 2013.

Josefson, A. B. and Widbom, B.: Differential response of benthic macrofauna and meiofauna to hypoxia in the Gullmar Fjord basin, Mar. Biol., 100, 31-40, 1988.

Kamykowski, D. and Zentara, S. J.: Hypoxia in the world ocean as recorded in the historical data set, Deep-Sea Res., 37, 18611874, 1990.

Kitazato, H., Nomaki, H., Heinz, P., and Nakatsuka, T.: The role of benthic foraminifera in deep-sea food webs at the sedimentwater interface: results from in situ feeding experiments in Sagami Bay, Frontier Research on Earth Evolution, 1, 227-232, 2003.

Lambshead, P. J. D. and Gooday, A. J.: The impact of seasonally deposited phytodetritus on epifaunal and shallow infaunal benthic foraminiferal populations in the bathyal northeast Atlantic the assemblage response, Deep-Sea Res., 37, 1263-1283, 1990.

Larkin, K. E. and Gooday, A. J.: Foraminiferal faunal responses to monsoon-driven changes in organic matter and oxygen availability at 140 and $300 \mathrm{~m}$ water depth in the NE Arabian Sea, DeepSea Res. Pt. II, 56, 403-421, 2009.

Levin, L. A., Blair, N. E., Martin, C. M., DeMaster, D. J., Plaia, G., and Thomas, C. J.: Macrofaunal processing of phytodetritus at two sites on the Carolina margin: in situ experiments using ${ }^{13}$ C-labeled diatoms, Mar. Ecol.-Prog. Ser., 182, 37-54, 1999.

Linke, P., Altenbach, A. V., Graf, G., and Heeger, T.: Response of deep-sea benthic foraminifera to a simulated sedimentation event, J. Foramin. Res., 25, 75-82, 1995. 
Loubere, P. and Fariduddin, M.: Benthic foraminifera and the flux of organic carbon to the seabed, in: Modern Foraminifera, edited by: Sen Gupta, B., Kluwer Academic Publishers, Dordrecht, 181-199, 1999.

Maas, M.: Verteilung lebendgefärbter benthischer Foraminiferen in einer intensivierten Sauerstoffminimumzone, IndoPakistanischer Kontinentalrand, nördliches Arabisches Meer, Meyniana, 52, 101-129, 2000.

Moodley, L., Middelburg, J. J., Boschker, H. T. S., Duineveld, G. C. A., Pel, R., Herman, P. M. J., and Heip, C. H. R.: Bacteria and foraminifera: key players in a short-term deep-sea benthic response to phytodetritus, Mar. Ecol.-Prog. Ser., 236, 23-29, 2002.

Nomaki, H., Heinz, P., Nakatsuka, T., Shimanaga, M., and Kitazato, H.: Species-specific ingestion of organic carbon by deep-sea benthic foraminifera and meiobenthos: in situ tracer experiments, Limnol. Oceanogr., 50, 134-146, 2005.

Nomaki, H., Heinz, P., Nakatsuka, T., Shimanaga, M., Ohkouchi, N., Ogawa, N. O., Kogure, K., Ikemoto, E., and Kitazato, H.: Different ingestion patterns of ${ }^{13} \mathrm{C}$-labeled bacteria and algae by deep-sea benthic foraminifera, Mar. Ecol.-Prog. Ser., 310, 95108, 2006.

Nomaki, H., Ogawa, N. O., Ohkouchi, N., Suga, H., Toyofuku, T., Shimanaga, M., Nakatsuka, T., and Kitazato, H.: Benthic foraminifera as trophic links between phytodetritus and benthic metazoans: carbon and nitrogen isotopic evidence, Mar. Ecol.Prog. Ser., 357, 153-164, 2008.

Nomaki, H., Ogawa, N. O., Takano, Y., Suga, H., Ohkouchi, N., and Kitazato, H.: Differing utilization of glucose and algal particulate organic matter by deep-sea benthic organisms of Sagami Bay, Japan, Mar. Ecol.-Prog. Ser., 431, 11-24, 2011.

Ohkushi, K. and Natori, H.: Living benthic foraminifera of the Hess Rise and Suiko Seamount, central north Pacific, Deep-Sea Res. Pt. I, 48, 1309-1324, 2001.

Pina-Ochoa, E., Koho, K. A., Geslin, E., and Risgaard-Petersen, N.: Survival and life strategy of the foraminiferan Globobulimina turgida through nitrate storage and denitrification, Mar. Ecol.Prog. Ser., 417, 39-49, 2010.
Raubenheimer, D. and Simpson, S. J.: Organismal stoichiometry: Quantifying non-independence among food components. Ecology, 85, 1203-1216, 2004.

Risgaard-Petersen, N., Langezaal, A. M., Ingvardsen, S., Schmid, M. C., Jetten, M. S. M., Opden Camp, H. J. M., Derksen, J. W. M., Pina-Ochoa, E., Eriksson, S. P., Nielsen, L. P., Revsbech, N. P., Cedhagen, T., and van der Zwaan, G. J.: Evidence for complete denitrification in a benthic foraminifer, Nature, 443, 93-96, 2006.

Sawant, S. and Madhupratap, M.: Seasonality and composition of phytoplankton in the Arabian Sea, Current Science, 71, 869-873, 1996.

Schumacher, S., Jorissen, F. J., Dissard, D., Larkin, K. E., and Gooday, A. J.: Live (Rose Bengal stained) and dead benthic foraminifera from the oxygen minimum zone of the Pakistan continental margin (Arabian Sea), Mar. Micropaleontol., 62, 4573, 2007.

Sweetman, A. K., Sommer, S., Pfannkuche, O., and Witte, U.: Retarded response by macrofauna-size foraminifera to phytodetritus in a deep Norwegian fjord, J. Foramin. Res., 39, 15-22, 2009.

Witte, U., Wenzhofer, F., Sommer, S., Boetius, A., Heinz, P., Aberle, N., Sand, M., Cremer, A., Abraham, W. R., Jorgensen, B. B., and Pfannkuche, O.: In situ experimental evidence of the fate of a phytodetritus pulse at the abyssal sea floor, Nature, 424, 763766, 2003.

Woulds, C., Cowie, G. L., Levin, L. A., Andersson, J. H., Middelburg, J. J., Vandewiele, S., Lamont, P. A., Larkin, K. E., Gooday, A. J., Schumacher, S., Whitcraft, C., Jeffreys, R. M., and Schwartz, M.: Oxygen as a control on seafloor biological communities and their roles in sedimentary carbon cycling, Limnol. Oceanogr., 52, 1698-1709, 2007.

Wyrtki, K.: Oceanographic Atlas of the International Indian Ocean Expedition, National Science Foundation, Washington, DC, 542 pp., 1971. 